\title{
Legal Liability of 'Free-Riders' during the COVID-19 Pandemic: A Mere Negligent Public Nuisance or Reckless Public Health Offence?
}

\author{
Jamila A. Chowdhury \\ Professor, Department of Law, University of Dhaka, Bangladesh
}

\section{INTRODUCTION}

Offences are not static - rather concepts of offences can transform over time, space and gravity. Social malice that was once not considered a crime may well be defined as a criminal offence in the course of time. For instance, Satipratha (burning widows on their husbands' funeral pyres) was an acceptable social norm which was not treated as a crime until the promulgation of the Bengal Sati Regulation 1829, which considered such actions as an offence. Likewise, adultery is not considered a criminal offence in the United Kingdom but is treated as both a moral wrong and a criminal offence in Bangladesh. Similar notion also applies to 'negligent' activities which usually (although not always) start without any criminal intention but crystallise over time, space and gravity and amount to a 'reckless' offence or are defined as a crime subject to more severe punishment. For instance, bats were considered the primary agent of SARS-related Coronavirus until a recent scientific discovery claiming the crossspecies jump of the virus from bats to human. ${ }^{1}$ Consequently, violation of SARS regulation now incurs enhanced penalty. ${ }^{2}$ Thus, determining the universal or static concept of an offence is not justified.

New laws relating to emerging issues are always being enacted or amended in many societies. Hinging on this dynamic notion of offence, this paper illustrates how the gravity of criminal offence caused by 'negligent' free-riders during COVID-19 outbreak has evolved from mere 'negligent public nuisance' ${ }^{\prime 3}$ to 'reckless public health offence ${ }^{14}$ around the globe. ${ }^{5}$ In this paper, 'free-riders' during COVID-19 pandemic

1 Jie Cui and others, 'Evolutionary relationships between bat coronaviruses and their hosts' (2007) 13(10) Emerging Infectious Diseases 1563.

2 Lawrence O Gostin et al., 'SARS and International Legal Preparedness' (2004) 77 Temple Law Review 155. See also, Tan Chorh Chuan, 'National Response to SARS: Singapore' (WHO Global Conference on SARS, Singapore, June 2003).

3 Section 180 of the Penal Code 2008 of UK stipulates that, "Any person who unlawfully does any act, or omits to do any act which it is his duty to do, not being an act or omission specified in section 179, by which act or omission harm is caused to any person, shall be guilty of an offence and liable on summary conviction to imprisonment for six month"”.

4 However, special law was enacted in many countries only for dealing this life-threating virus. For example, the Coronavirus Act 2020 (UK), which was enacted on 25 March 2020, under the head of Health protection regulations provides that, "(a) may not create an offence punishable with a fine exceeding $£ 10,000 ”$.

5 See also, The Health Protection (Coronavirus, Wearing of Face Coverings in a Relevant Place) 
signify people in a given society, who do not comply with prescribed health guidelines (e.g. wearing masks, social distancing, quarantine rules, isolation rules etc.) set by the World Health Organization (WHO) and the Government of Bangladesh to curb the communal spread of the highly contagious Coronavirus. ${ }^{6}$ The Stanford Encyclopaedia of Philosophy defines it as "someone who receives a benefit without contributing towards the cost of its production" $"$. Therefore, the imposition of restriction and penalty on reckless free-riding is essential to establish fairness and justice in society. As explained in Hart's Principle of 'Mutuality of Restriction'

when a number of persons conduct any joint enterprise according to rules and thus restrict their liberty, those who have submitted to these restrictions when required have a right to a similar submission from those who have benefited by their submission.

Accordingly, this paper urges policymakers of Bangladesh to make 'free-riders' criminally liable with prompt and stringent punishments, especially for their 'reckless' behaviour manifest in repeated violations of health regulations. For instance, according to Section 34(7) of the COVID -19 (Temporary Measures) Act, 2020, of Singapore, 'differential monetary penalty' and penal provision is suggested for a person who violates COVID-19 regulations. It states that a person who, without reasonable excuse, contravenes a control order, commits an offence and shall be liable on conviction-

(a) to a fine not exceeding $\$ 10,000$ or to imprisonment for a term not exceeding 6 months or to both; or

\section{(b) in the case of a second or subsequent offence, to a fine not exceeding $\$ 20,000$ or to imprisonment for a term not exceeding 12 months or to both.}

Thus, penalty provision for the violation of COVID-19 related regulation in Singapore effectively differentiates between first time violation and frequent or repetitive violations of health regulations. ${ }^{9}$

(England) Regulations 2020; The Corona Virus Act, 2020 (Philippines) (Republic Act No. 11469) which came into existence on 24 March 2020; the COVID-19 (Temporary Measures) Act 2020 (Singapore) etc.

6 According to Section 9 of the Communicable Diseases (Prevention, Control, and Eradication) Act, 2018, the 'International Health Regulations' published by WHO, after necessary adaptations, will be applicable to procedural measures for protecting public rights against the spread of communicable diseases in Bangladesh; See, Communicable Diseases (Prevention, Control, and Eradication) Act, 2018 (Bangladesh) (s 24). As COVID- 19 is a global pandemic spreading across continents, compliance with some internationally recognized standard operating procedure for its prevention, control and eradication would be commendable. See, David P Fidler, 'Globalization, international law, and emerging infectious diseases' (1996) 2(2) Emerging Infectious Diseases 77.

7 Russell Hardin, 'The Free Rider Problem' (Stanford Encyclopaedia of Philosophy, First published 2003, 2020) <https://plato.stanford.edu/entries/free-rider/> accessed 25 January 2021.

8 Herbert L Hart, 'Are There any Natural Rights?' (1955) 64 Philosophical Review 175, 185.

9 Doctrine of enhanced punishments were incorporated for the subsequent violation of the same offence earlier done. See also the Penal Code 1860 (No. XLV of 1860), s 75 where it states that, "Whoever, having been convicted by a Court in Bangladesh of an offence punishable under Chapter XII or Chapter XVII of this Code with imprisonment of either description for a term of three years or upwards, shall be guilty of any offence punishable under either of those Chapters with like 
Surprisingly, much before the enactment of this 'new' law in 2020 in Singapore for curbing COVID-19 pandemic, the Penal Code 1860, applicable in Bangladesh, inserted the Doctrine of enhanced punishment for a second or subsequent offence. ${ }^{10}$ Section 291 of the Penal Code 1860 (Act No. XLV of 1860) stipulates that:

Whoever repeats or continues a public nuisance, having been enjoined by any public servant who has lawful authority to issue such injunction not to repeat or continue such nuisance, shall be punished with simple imprisonment for a term which may extend to six months, or with fine, or with both.

Although the term 'reckless' is not defined in the Penal Code 1860, it can be explained, based on the Cambridge dictionary, as doing something hazardous and not worrying about the risks and the possible results. Oxford Law Dictionary further defines 'recklessness' as "a form of mens rea that amounts to less than intention but more than negligence".

The 'novel' Coronavirus (COVID-19) is a life-threatening virus, which is highly infectious and deadly in nature, and which has taken millions of lives worldwide ${ }^{11}$ since its detection in January 2020. Consequently, the World Health Organisation (WHO) has declared COVID-19 as a 'Pandemic' after two months of its first detection in China $^{12}$. It gradually spread to almost all countries in the world. On the related note, the Health Directorate-General of Health Services of the Ministry of Health, Bangladesh issued a notification on 24 March 2020 flagging that the whole country was endangered to COVID-19 risk and their respective preparedness in this regard ${ }^{13}$.

imprisonment for the like term, shall be subject for every such subsequent offence to imprisonment] for life, or to imprisonment of either description for a term which may extend to ten years". Similarly, see the Laws of Malaysia (Act 574), s 75.

10 The Penal Code 1860 (Bangladesh), Chapter XIV: of Offences Affecting the Public Health, Safety, Convenience, Decency and Morals. Though the Penal Code 1860 does not have any provision for quarantine of individuals, according to Sec 271, whoever knowingly disobeys any government promulgation to keep any vessel in quarantine shall be punished with an imprisonment of both either description that may extend up to six months, or with fine or both. Thus, considering the similarity in context and penalty provisions discussed under Sec 271 and 291, it will not be unjustified if we apply Sec 291 to punish those 'free riders' who knowingly violate the self-quarantine rule of the Government and roam around recklessly and contribute transmission of the highly contagious and life-threatening virus.

11 Deaths, 'COVID 19 Coronavirus Pandemic' worldometer <https://www.worldometers.info/ coronavirus/?utm_campaign=homeAdvegas 1?\%22> accessed 25 January 2021.

bdnews24.com (Online, 23 March 2020) <https://bdnews24.com/bangladesh/2020/03/23/its-officialbangladesh-lists-covid-19-as-a-communicable-disease> accessed 18 August 2020.

12 News: Coronavirus Pandemic, 'Timeline: How the new coronavirus spread' (Al-Jazeera Online, 20 September 2020) <https://www.aljazeera.com/news/2020/9/20/timeline-how-the-new-coronavirusspread $>$ accessed 11 September 2020.

13 Nasima Sultana, 'Status of Noble Corona Virus 2019' (Press Briefing, 24 March 2020) <https://corona.gov.bd/storage/press-releases/March2020/press-release_2020_03_24.pdf> accessed 22 September 2020. To restrain the spread of the Coronavirus, the Government has recently postponed the Junior School Certificate examinations that are held annually nationwide. Please see Star Online Report, 'Junior School Certificate, equivalent exams won't be held this year' The Daily Star (Dhaka, 27 August 2020) <https://www.thedailystar.net/country/news/junior-school-certificate-equivalentexams-wont-be-held-year-1951893> accessed 20 January 2021.

Page | 176 
Due to the absence of any vaccine or other workable remedies, the WHO has declared a series of preventive measures against this deadly viral disease, including wearing masks and maintaining social distancing, quarantine rules, and isolation guidelines which were deemed as the only functional alternatives to mitigate its community transmission. Furthermore, scientists of different countries, including the UK, Australia and India, 'warned their policymakers against the increase in transmission of COVID-19 during winter' as 'the winter may environmentally favour coronavirus transmission'. A group of scientists from the University of Sydney, Australia warned about the gravity of this 'new wave' by suggesting that 'a one per cent fall in humidity could increase the number of infections by six per cent ${ }^{\prime} .^{14}$

Hence, the enactment of new laws in different counties with more stringent punishment, aimed at deterring the spread of coronavirus infection, was imperative, more particularly as world authorities were apprehending a 'second wave' of COVID19 in the coming winter. ${ }^{15}$ In this regard, this paper has identified existing legal provisions, their recent evolution, and lack of implementation to adequately address the COVID-19 related health risks in Bangladesh. Analysing relevant legislative provisions and associated implementation strategies followed in the UK and other countries, including Singapore, India, and Sri Lanka, this paper emphasises on strategic legal provisions to improve the effectiveness of existing laws in this regard. If adopted, these legal provisions can effectively separate those who 'negligently' violate health regulations from those 'reckless free-riders' who repeatedly disregard health guidelines and violate Government regulations over and over again.

\section{REVISITING THE ELEMENTS OF CRIME: FROM 'INTENTION' TO 'NEGLIGENT' AND 'RECKLESS' ACT AS MENS REA}

A person may commit a criminal offence when s/he does something, which is legally prohibited, or omits to do something, which he is legally bound to do. However, to consider an act or omission as crime, it must fulfil some pre-defined criteria, usually termed as elements of a crime. 'As a matter of simple analysis, we can think of a crime as being made up of three ingredients: actus reus, mens rea, and the absence of a valid defence $^{16}$ According to the vital principle of English criminal law - Actus non facit reum nisi mens sit rea (i.e. a crime is not committed if the mind (mens rea) of the

14 'Coronavirus likely to hit Bangladesh harder in winter' The Daily Prothom Alo (Dhaka, 25 July 2020) $<$ https://en.prothomalo.com/bangladesh/coronavirus-likely-to-hit-bangladesh-harder-in-winterexperts> accessed 12 September. See also, UNB News, 'Prepare for Covid's second wave in winter: PM to admin' United News of Bangladesh (Dhaka, 21 September 2020) $<$ https://unb.com.bd/category/bangladesh/prepare-for-covids-second-wave-in-winter-pm-toadmin/57763> accessed 22 September 2020. Authorities around the globe made similar predictions. See also, Joel Achenbach and Rachel Weiner, 'Experts project autumn surge in coronavirus cases, with a peak after Election Day' Washington Post (Washington, 5 September 2020) $<$ https://www.washingtonpost.com/health/coronavirus-fall-projections-secondwave/2020/09/04/6edb3392-ed61-11ea-99a1-71343d03bc29_story.html> accessed 12 September 2020. Ibid.

16 David Lanham, 'Larsonneur Revisited' (1976) Criminal Law Review 276-281. 
person doing the act in question is innocent, and the guilty mind and act must both exist at the same time). For a criminal offence, the matter of 'innocence' is not a moral issue, rather it is usually defined by law.

\section{A. Meaning of Mens Rea in a Crime}

The maxim 'actus non facit reum nisi mens sit rea' (i.e. the act is not culpable unless there is a guilty mind) is one of the cardinal principles of criminal law. ${ }^{17}$ The literal meaning of mens rea is 'guilty mind'. This is because the definitions of various offences contain express propositions as to the state of mind that is requited of an accused. The definitions of various offences generally imply whether the act was done 'intentionally,' 'voluntarily,' 'knowingly,' 'dishonestly' or 'fraudulently,' and so on. Therefore, mens rea will mean one thing or another based on the particular offence. In other words, mens rea may signify a fraudulent mind, or a dishonest mind, or even a negligent or reckless mind. Every offence under the Penal Code, 1860 describes the requisite of mens rea in an offence in some form or the other.

The term 'mens rea' is not explicitly used in the Penal Code, 1860 (hereinafter referred to as the Code, 1860). Nevertheless, its essence is found in different terms. Words commonly used to denote this is 'state of mind', including intention, knowledge, recklessness, negligence, etc. It is pertinent to mention that different types of mens rea form a hierarchy, with intention and knowledge being the most grave in extent, followed by recklessness and negligent act. There are other specific forms of mens rea arising in individual offences, which are difficult to fit within this hierarchy. ${ }^{18}$ For example, under the Code 1860, the state of mind required for the crime of theft is 'dishonesty' (s. 378). Cheating must be committed 'fraudulently', while murder must be committed either 'intentionally' or 'knowingly'.

Each definition of an offence under the Code, 1860 underpins the requisite state of mind of the accused when he was committing the act. Generally, if a criminal act is committed, and it can be established that the act was done with any of the states of mind as mentioned above, the requisite mens rea can be said to have been present. Notwithstanding, the determination of the various states of mind that constitute dishonesty or fraudulence remains a challenge, and countries choose to adopt ways to determine them based on contextual priorities. For example, the Model Penal Code of USA defines mens rea as a continuum of four states of mind starting from the 'most of guilty mind' to the 'least of guilty mind' during the occurrence of an event. These are:

- Intention;

17 According to Section 32 of the Penal Code, 1860, "in every part of this Code, except where a contrary intention appears from the context, words which refer to acts done extend also to illegal omissions." Section 33 further denotes that, "the word "act" denotes as well a series of acts as a single act: the word "omission" denotes as well a series of omissions as a single omission".

18 David Ormerod, Criminal Law (13 ${ }^{\text {th }}$ edn, Oxford University Press 2011) 106.

Page $\mid 178$ 
- Knowledge;

- Recklessness; and

- Negligence.

Further to the state of a criminal mind of an offender as defined in a point of time during the occurrence of a crime, there is another state of social mind that collectively defines or considers a particular act or omission to be a crime. This social state of mind also has a specific nature. That is to say, when the gravity and frequency of a criminal offence in a society increase progressively, less culpable offences may be defined as more grievous crimes. In other words, non-cognisable offences may become cognisable and attract punishment in due course of time as it seemingly causes great social malaise. For instance, eve-teasing is not a new phenomenon in Bangladesh. A social movement emerged against eve-teasing, culminating in High Court Division directives against sexual harassment in workplaces and educational institutions. The Court advised against the use of the term euphemistic "eve-teasing" and defined circumstances, including unwanted contact through cell phones, mobile, email or any other media that may reasonably cause a woman to feel endangered about her safety. This is an example of how new forms of criminal acts get recognition and are emancipated from euphemistic use. However, punishing such crimes is often challenging, as offenders usually defend an absence of their intent of knowledge or describe it as an accident, despite the lack of negligence.

\section{B. "Absence of Guilty Mind is No Excuse" for Many Crimes}

As noted earlier, generally speaking the definition of crime contains expressly, or by implication, a description of the state of mind required to commit such a crime. "Although prima facie and as a general rule, there must be a mind at fault before there can be a crime, it is not an inflexible rule, and a statute may relate to such a subject matter and may be so framed as to make an act criminal whether there has been any intention to break the law or otherwise to do wrong or not". ${ }^{19}$ These are 'strict liabilities' in law that do not consider the mental state of the person who committed that offence. Thus, if the mental element of any conduct alleged to be a crime is proved to have been present in any given case, the crime so defined is committed, no matter what. On the other hand, if a crime is defined, any act or omission may amount to that crime if it falls within that definition, no matter what. As such, there are some crimes where the maxim 'actus non facit reum nisi mens sit rea' has no spontaneous application under the criminal law. As mentioned, the presence of a guilty mind is not necessary when any offensive behaviour is tagged with strict legal liability.

For the purposes of this paper, the principle of mens rea may not be essential in some cases, such as:

- in matters concerning public health, food, drugs etc.; where mere negligence may not be tolerated due to a public safety concern;

- where a statute imposes strict liability; ${ }^{20}$ and

19 James W. Cecil Turner and Arther L. Armitage, Cases on Criminal Law ( ${ }^{\text {rd }}$ edn, Cambridge University Press 1964) 17.

20 Strict liability refers to those offences for which no mens rea or even negligence is required. These 
- in cases concerning public nuisance.

\section{Concurrence of 'Mens Rea' and 'Actus Reus' May be Attributed Rather Than Actual: The 'But For' Principle to Prove Actus Reus}

Commission of a crime is possible without a criminal mind or when people are not knowingly or intentionally committing an illegal activity. Therefore, the actus reas gets more importance in determining criminal liability. In the absence of a guilty mind, to prove the crime of the accused, it must be proved that the crime would not have been committed 'but for' the actus reas (reckless or negligent act or omission) of the offender. If this test is met, the alleged offender is held liable for committing the offence. Hence, the essence of this 'but for' principle is that criminal liability arises for acts or omissions that may constitute the 'proximate cause' of the harm - not constitute mere 'remote causes. ' It is based on the maxim' causa proxima, non remota spectator': essentially, the immediate, and not the remote cause, is essential. Thus, imagine that $\mathbf{X}$, a clinically tested COVID-19 patient, invites his business partner $\mathbf{B}$ to have dinner at $\mathbf{X}$ 's house and sign their next business deal. Just after his return, $\mathbf{B}$ got sick and later died in a hospital after testing Corona +ve. As $\mathbf{B}$ got ill and was hospitalised just after visiting a clinically tested COVID-19 patient $\mathbf{X}$ and having dinner with him, it could be considered a proximate cause of $\mathbf{B}$ 's death.

Courts sometimes have to struggle determining the proximate cause of a crime, as actus reas get prominence in an offence. Determining criminal liability, therefore, becomes more difficult. For instance, in the Jordan case, ${ }^{21} \mathbf{O}$ stabbed $\mathbf{P}$, admitted to the hospital and died eight days later. In this case, $\mathbf{O}$ was initially held liable for causing the death of $\mathbf{P}$. However, in the Court of Criminal Appeal, due to the submission of fresh evidence by two doctors, it was observed that death had not been caused by the stab wound, which had primarily healed at the time of death. Instead, the cause of death was the 'negligence' of medical personnel in providing treatment. The Court of Appeal held that "if the jury had heard this evidence, they would have felt precluded from saying that they were satisfied that the stab wound caused the death and they quashed the conviction."122 The 'but for' principle relates to whether the accused's act (the factual cause of criminal harm) was 'probable' and 'foreseeable'.

Further, it should be kept in mind that the 'but for' principle is the starting point of the causation inquiry, but not a conclusive one. In the example of COVID-19 case mentioned above, if $\mathbf{X}$ had worn a mask when meeting $\mathbf{B}$, used disinfectants,

offences are constituted without require to prove fault. See more on Jeremy Horder, 'Strict Liability: Statutory Construction and the Spirit of the Liberty' (2002) 118 Quarterly Law Review 458; Kiron Reid, 'Strict Liability: Some Principles or Parliament' (2008) 29 St LR 173. However, there are considerable criticisms against offences with strict liability. It is argued that there are some difficulties of imposing strict liability, particularly, in offenses of serious nature. 'There is real sense of unfairness in convicting someone for conduct which on his part was "faultless".' See further Duff (n 29) Ch 10.

$21 \quad R$ v Jordan (1956) 40 Cr App R 152, 155.

22 Ibid.

Page $\mid 180$ 
maintained a distance and informed $\mathbf{B}$ that he had tested Corona positive, he could have pleaded the exercise of due care and ask the court to consider the event as an accident.

In the COVID-19 instance stated above, one major hurdle for prosecution to frame an offence is to establish both actus reus and mens rea. In common understanding, it has to be established that they occurred simultaneously - a concurrence of mens rea and actus reus. There must be a guilty mind behind the act itself - crime is not committed if the mind of the person committing the said relevant act is innocent. As mentioned earlier, the principle is based on the maxim actus non facit rum nisi mens sit rea, meaning that the act itself does not constitute guilt unless done with a guilty intent. The Model Penal Code of USA states that "Where the relationship between the mens rea and the result are at issue because the crime in question requires that there be concurrence between the mens rea and the result (as opposed to the act), the prosecution must show that the result was attributable to the mens rea in order to sustain a conviction. ${ }^{123}$ Hence, in the above COVID-19 example, as $\mathbf{X}$ knew he was COVID+ve, $\mathbf{X}$ should have remained in isolation and informed $\mathbf{B}$ about his infection in a conscious effort to avoid infecting him. Suppose, it was necessary to sign the contract in person. In that case, $\mathbf{X}$ should have taken all necessary preventive measures, including informing $\mathbf{B}$ about his condition to protect against potential infection. In this context, B's family may charge $\mathbf{X}$ with 'reckless' behaviour.

Therefore, even with the absence of any strict liability of a COVID positive patient, B's death could be attributed to the reckless behaviour of $\mathbf{X}$. That said, X's activities could still be considered negligent even if he was not aware that he was COVID positive since he failed to conform to standard health guidelines. The Model Penal Code of the USA makes a distinction between 'reckless' and 'negligent' behaviour. "Although the level of risk is the same for both recklessness and negligence, the difference between the two is that with recklessness, the actor must be aware of the risk involved with her actions, whereas, for negligence, the actor is not aware of the risks but should have known (hazards) what those risks were". ${ }^{24}$ By applying this distinction, the criminal liability of a COVID-19 patient may be linked with 'reckless' behaviour which is likely to increase aggregate harm to society without intending to cause anyone harm.

\section{Indirect Attribution to Aggregate Harm May Suffice to Attract Criminal Liability}

Attribution of mens rea would be applicable even when the actus reus may cause 'collective harm' and the particular person suffering harm may not be explicitly

23 See more, The American Law Institute, 'Model Penal Code: Official Draft and Explanatory Notes' (The American Law Institute 1985) sec 2.02, $25<$ https://www.legal-tools.org/doc/08d77d/pdf> accessed 7 March 2021. 
identified. Indirect attribution of harm through actus reus suffice to attract criminal liability. Professors Gardner and Shute define the 'Harm principle' as follows:

It is enough to meet the demands of the harm principle that, if the actions were not criminalised that would be harmful ... Non-instrumental wrongs, even when they are perfectly harmless in themselves, can pass this test if their criminalisation diminishes the occurrence of them, would detract from people's prospects - for example, some public good..$^{25}$

Hence, these events would be an issue of public justice and should be dealt with by the State. Individuals may inform the Government authority about the malicious behaviour of a person. However, because of the indirect nature of harm, an individual may not have sufficient locus standi to deal with these cases. Along the same line, 'reckless' or 'negligent' behaviour of an individual that may transmit noxious diseases is already declared as criminal activity under the Communicable Diseases (Prevention, Control, and Eradication) Act 2018, hereinafter mentioned the 2018 Act. ${ }^{26}$ Further, the Mobile Courts Act, 2009 has already included relevant sections of 2018 Act in its Schedule. ${ }^{27}$ In the 2018 Act, compliance with safety measures, such as wearing a face mask, has not yet defined as strict liability, unlike using safety equipment while working in a factory or a construction site ${ }^{28}$. Hence, at present, there is no legal provision for alleviated punishment to 'free-riders' in Bangladesh, who 'persistently' violate requisite health guidelines during the COVID-19 pandemic.

\section{COHESION IN CRIMINAL LAWS: A CROSS-CUTTING DIVERSITY}

Although conceptualising a crime as a universal or single concept is not possible, some characteristics of crime can be generalised. According to Duff, it is hard to find:

some single concept or values that will capture the essence of crime or the essential characteristic in virtue of which crimes are properly punished ... in favour of pluralism that recognises a diversity of reasons for criminalisation, matching the diversity of kinds of a wrong which can legitimately be the criminal law's business. ${ }^{29}$

Therefore, while analysing the mens rea involved in reckless movement during COVID-19, this paper follows a general principle suggested by the American Law Institute. It is pertinent to mention here that, in general, the key characteristic of the criminal law is to set out primarily the boundaries of acceptable behaviour for the

25 John Gardner and Stephen Shute, 'The Wrongness of Rape' in Jeremy Horder (ed), Oxford Essays in Jurisprudence (Fourth series, Clarendon Press 2000) 216; See also Jeremy Horder, 'Bribery as a form of criminal wrongdoing' (2011) 127 Law Quarterly Review 37; Andrew von Hirsch and Nils Jareborg, 'Gauging Criminal Harm: A Living Standard Analysis' (1991) 11 Oxford Journal of Legal Studies 1. See further Chris Clarkson, 'Aggravated Endangerment' (2007) 60 Current Legal Problems 279.

27 See, bdnews24.com (n 49); See also, The Daily Star (n 51).

28 Bangladesh Labour Code 2006, s 78(A).

29 Anthony Duff, Answering for Crime: Responsibility and Liability in the Criminal Law (Hart Publishing 2007) 139.

Page | 182 
people of a State, and the power of the State to inflict punishment on those acting beyond those boundaries. Acknowledging the diversity in boundaries that define crime in different societies, "the definition of offences" in the American Law Institute's Model Penal Code can be taken as the basis of criminal law in a modern legal system. According to this Code, the aims of criminal law are:

- To prevent offences or conducts that unjustifiably and inexcusably inflicts or threatens substantial harm to the individual or public interests;

- To impose public control on persons whose conduct indicated that they are disposed to commit an offence;

- To safeguard conducts from without fault condemnation as a criminal offence;

- To give reasonable warning of the nature of the conduct declared to be an offence;

- To differentiate between serious and minor offences. ${ }^{30}$

The purposes of the criminal law are discharged by the criminal justice system, particularly by law enforcement agencies following the five propositions prescribed in the American Model Penal Code. ${ }^{31}$ These form the "basic ethical building blocks of the criminal law". ${ }^{32}$ Although these five propositions are defined as basic, principled and humane purposes of criminal law, they "fail adequately to account for the majority of criminal laws in operation". ${ }^{33}$ Amongst these five propositions, clause (1) is a convenient starting point for discussing the aims of criminal law, since it deals with the concept of the 'public interest'. The significance of the concept of 'public interest' in defining crime is acknowledged by Duff:

We should be held criminally responsible for wrong-doings, which are public in the sense that they properly concern all members of the polity and merit a formal public response of censure and condemnation. ${ }^{34}$

As discussed, the notion of crime may vary in society, and it may evolve over time. As society gets more sophisticated, the gravity of the same offence, especially those related to privacy and personal safety, may increase over time. The following section deals with the dynamics of criminal offences, particularly offences by negligence, which constitute a core argument of this paper.

\section{LEGISLATIVE RESPONSES AGAINST NEGLIGENT AND RECKLESS MOVEMENT DURING PANDEMIC: HISTORICAL PRACTICE IN HEALTH EMERGENCIES AND CURRENT TREND UNDER COVID-19}

The practice of limiting contagious and virulent diseases through isolation of infected

\footnotetext{
30 Nigel Walker, The Aims of the Penal System (Edinburgh University Press 1966).

A. ${ }^{31}$ Liz Campbell, Andrew Ashworth, and Mike Redmayne, The Criminal Process $\left(5^{\text {th }}\right.$ edn, Oxford University Press 2019).

32 William Wilson, Criminal Law (5 ${ }^{\text {th }}$ edn, Pearson Education Limited 2014).

33 Ibid, 5.

34 Duff (n 29) 123.
} 
patients can be traced back to Egypt around 1250 BC when Ramses II ordered the evacuation of nearly 80,000 leprosy patients and resettle them on the edge of the Sahara $\operatorname{desert}^{35}$. The 'notion of quarantine' evolved much later in $14^{\text {th }}$ century Europe when countries in Europe were affected by the Plague when, according to different estimates, almost one quarter to half of the population of Europe died during a four-year period 1347 to $1350^{36}$. Following this deadly consequence, in 1377, one Italian ruler Viscount Reggio prohibited anyone from a Plague affected area from entering Reggio, with a penalty of death penalty attached to the violation of his order. ${ }^{37}$ This order is considered the beginning of the current-day notion of quarantine when the authority also controls the movement of people who are suspected of being infected with an contagious disease. Another striking feature was the harshness and promptness of the penalty imposed on people in violation of the quarantine rule.

Although the process of isolation was an established idea, the practice of avoiding people coming in from infected areas that had originated in Italy, began to spread throughout Europe. In 1448, the Venetian Senate, passed the 'first quarantine law', ordering every person or ship coming in from an infected region to remain isolated. ${ }^{38}$ The first law allowed a 30-day isolation of patients affected by the Plague. Many countries later replicated this law. The term 'quarantine' evolved as the period of isolation was increased from 30 to 40 days. This new term replicated the Latin term 'quadraginta' which referred to 40-day detentions of ships. ${ }^{39}$ The notion of quarantine was also applicable to other nations of Europe, albeit with greater harshness towards those who violated the quarantine rule, just to curb its mass and community transmission. In Germany, the measures were so harsh that even death was not an excuse to avoid punishment for any violation of quarantine rules. For instance, once, when a servant girl in Germany died of Plague, and it was discovered after her burial that she had violated the health Code, her dead body was exhumed from the grave, then dangled inside the coffin and burnt after a couple of days. All these were done to raise public awareness against violation of health regulations ${ }^{40}$.

The notion of quarantine regulations appeared in the law of the United States almost two centuries after it was first applied in Europe. Quarantine regulations were first introduced in the Massachusetts Bay Colony in 1647 when they were imposed on ships coming from Barbados for fear of Plague. ${ }^{41}$ Almost 15 years later in 1662, the first

35 John H. Kilwein, 'Some historical comments on quarantine: part one' (1995) 20 Journal of Clinical Pharmacy and Therapeutics 185-7.

36 Martha Anker and D. Schaaf, WHO report on global surveillance of epidemic-prone infectious diseases (World Health Organization 2000) 25; see also, Jenny Howard, 'Plague was one of history's deadliest diseases-then we found a cure' (National Geographic, 6 July 2020) $<$ https://www.nationalgeographic.com/science/health-and-human-body/human-diseases/the-plague/> accessed 25 January 2021.

37 Kilweing (n 35).

38 Philip A. Mackowiak, 'The origin of quarantine' (2002) 35 ARCANUM 1071.

39 Kilwein (n 35) 186.

40 Kenneth Walker, The Story of Medicine (New York: Oxford University Press 1955).

41 LEDA, 'Origins of Federal Quarantine and Inspection Laws' Harvard Law School 
land-based quarantine law was used in a town of East Hampton, Long Island. The 'prompt and harsh punishment' was also evident from the notice placed at the entry in the town:

...that no Indian shall come to town into the street after sufficient notice upon penalty of 5s. or be whipped until they be free of smallpox... and if any English or Indian servant shall go to their wigwams, they shall suffer the same punishment. $^{42}$

The historical perspectives on the 'prompt and harsh actions' taken by different countries during similar public health emergencies demonstrate the seriousness of the offence of health regulation violation and indicate the possibility of strenghething of the implementation of health directives by imposing strict restrictions.

\section{A. Legal Liability for 'Negligent' or 'Reckless' Movement during the COVID-19 Pandemic: Bangladesh Perspective}

On 14 November 2018, the Government of Bangladesh passed a new law titled the Communicable Diseases (Prevention, Control, and Eradication) Act $2018^{43}$ (hereinafter mentioned as the 2018 Act). Section 4 of the Act 2018, which replaced the Epidemic Diseases Act 1897, lists many known diseases, including typhoid, influenza, diarrhoea, tuberculosis, nipa, Ebola, meningitis, etc. as a contagious disease $^{44}$. Although the spreading of infectious diseases has been discussed earlier as a variation of 'public nuisance' under Section 268 of the Code, 1860, the Act of 2018 is first of its kind in Bangladesh which has categorically inserted some contagious diseases. This law has many features, including the declaration of lock-down in areas, quarantine and isolation of any person suffering from severe infectious diseases, etc. ${ }^{45}$. The Act of 2018 has given the government the authority to add more diseases to this with the emergence or re-emergence of diseases over time. As a result, the government has incorporated COVID-19 in the Act of 2018 by a Gazette on 23 March 2020 with retrospective effect from 08 March 2020 - the day the first confirmed COVID-19 patient was identified in Bangladesh.

Thus, as the COVID-19 pandemic mostly embraces all provisions of the Act of 2018, the 2018 Act legally served as a good regulatory tool for the government during this outbreak. Section 24 of the Act of 2018 provides that any known spread of the virus is a criminal offence punishable with a monetary penalty up to Taka 100,000 or

<https://dash.harvard.edu/bitstream/handle/1/8852098/vanderhook2.html?sequence=4> accessed 20 Sep 2020.

42 Ralph Chester, The United States Public Health Service, 1798-1950 (Commissioned Officers Association of the United States Public Health Service, Washington, D.C., 1951) 63.

43 The Infectious Disease (Prevention, Control, and Elimination) Act 2018.

44 Ibid, s 4.

45 WHO Bangladesh, 'COVID-19' (Situation Report No 8, 2020). According to Sec 14 of the 2018 Act, if an authorized person has reason to believe that, an infected person, if not isolated, may get other people infected, then, following prescribed rules, such person can be transported to other place or quarantined. 
imprisonment up to 6 months or both ${ }^{46}$. Therefore, any Corona positive patient, who, due to his/her reckless free-riding, spreads the deadly virus may be prosecuted under this section. Section 25 of the Act further provides that any person who refuses to comply with any government order for the prevention, control, and eradication of any infectious disease shall be punished with a fine of up to Taka 50,000 or imprisonment up to 3 months or both ${ }^{47}$. Therefore, any person who violates the quarantine rule or leaves the house without a mask can be prosecuted under Section 25 of the Act of 2018. Section 14 of the Act empowers the government to enforce 'quarantine' and 'isolation' rules against any infected person. These provisions are almost similar to the criminal liabilities implied as a public nuisance under the Code $1860 .^{48}$

However, there were at least two initial but vital limitations to the implementation of the provisions of the 2018 Act. Initially, COVID-19 was not included in the Schedule of the Act until the High Court Division of the Supreme Court of Bangladesh ordered the government to include COIVID-19 in the Schedule of the law. ${ }^{49}$ As a result, although Section 24 of the Act does not provide for harsher punishment for the violation of public safety regulation related to a contagious disease, a 'quick response' by the law enforcement to violation of Coronavirus related health guidelines was not possible as the criminal offences under the 2018 Act were not included in the Schedule of the Mobile Courts Act, 2009. In order to provide a quick remedy, on 31 May 2020, the Ministry of Home Affairs directed the Police, RAB and other law enforcing agencies to assist the local administration in operating mobile courts to monitor compliance with health directives like, the use of masks, social distancing, hand washing and observing other safety measures. ${ }^{50}$ Thus, pursuant to the provisions of the 2018 Act, the Mobile Courts can now take cognisance of certain criminal activities and impose on-site punishment, including imprisonment. ${ }^{51}$ Given that the Mobile Courts Act, 2009 is a procedural law, ${ }^{52}$ the awarding of penalties will be guided by the substantive law provisions, in this case - the Act of 2018.

\section{Box 1: Punishments attributable to the spread of COVID-19 under the Communicable Diseases (Prevention, Control, and Eradication) Act, 2018}

Section 24 (1) If any person spreads or aid in spreading the infection of any communicable disease, or knowingly suppress from other people the risk of being infected while coming in touch with any infected

46 The Infectious Disease Act (n 43), s 24.

47 Ibid, s 25.

48 The Penal Code 1860, ss-268-270.

49 bdnews24.com, 'it's official: Bangladesh lists COVID-19 as a communicable disease' (bdnews24.com, 23 March 2020) <https://bdnews24.com/bangladesh/2020/03/23/its-officialbangladesh-lists-covid-19-as-a-communicable-disease> accessed 10 September 2020.

50 Tribune desk, 'Mobile courts to monitor health guidelines' Dhaka Tribune (Dhaka, 30 May 2020) <https://www.dhakatribune.com/bangladesh/2020/05/30/mobile-courts-to-monitor-healthguidelines> accessed 2 September 2020.

51 Law Desk, 'The Laws Relating to Communicable Diseases' The Daily Star (Dhaka, 14 April 2020).

52 Mobile Courts Act 2009.

Page | 186 
person or facility then such act of that person constitutes a crime.

(2) Whoever commits an offence under subsection (1) shall be punished with imprisonment for a term, which may extend to six months, or with fine not exceeding Tk. 1 lac, or with both.

\section{Source: Communicable Diseases (Prevention, Control, and Eradication) Act, 2018}

Although the government has announced COVID-19 as a 'pandemic' and stressed that 'risk' extended to the whole of Bangladesh, its relegation to the level of 'negligent public nuisance' in some legal texts created some confusion. Also, there is a lack of public awareness about the gravity of the infection and the importance of following the health guidelines as suggested by the concerned authority. By the authority vested on it by the Act, the government issued a notification on 30 May 2020, whereby the use of facial masks and the maintenance of social distancing outside of the home was made mandatory, and violation of this order was made punishable (i.e. fine and imprisonment). Nevertheless, it was observed that the implementation of the penalties was somewhat slack in violation of Section 24 of the Act of 2018. The following Table demonstrates the low and varying imposition of fines in different places, indicating flexibility of law enforcement agencies in penalising offenders for violation of COVID-19 health guidelines.

Table 1: Fines imposed for violation of COVID-19 regulation, April-June 2020

\begin{tabular}{lllll}
\hline Area & No of cases & Total fine & Avg. fine & Source \\
\hline Bagerhat & 39 person & 36900 & 946.15 & UNB; 4 June 2020 \\
\hline Dhaka & 15 person & 15,600 & 1040.0 & Dhaka Tribune; 2 May 2020 \\
\hline Rajshahi & 1 Institution & 10,000 & 10,000 & $\begin{array}{l}\text { The Business Standard; 1 } \\
\text { April 2020c }\end{array}$ \\
\hline
\end{tabular}

Imprisonment under the Act 2018 is also challenging during the COVID-19 crisis, as special arrangements are required to keep these detainees away from other prisoners. Thus, on-spot punishment consisting of a hefty monetary penalty for the reckless spread of the infection seems more appropriate in this context. ${ }^{53}$

While some Asian countries declared curfew or imposed a lock-down immediately after detecting the first Corona positive patient in their respective jurisdictions, the Bangladesh government instead proclaimed a two-week national holiday after the first detection of a COVID-19 positive patient in the country. On 21 July 2020, the Health Services Department of the Government issued a circular making the wearing of masks mandatory when the number of total infections had already reached as high as $210,510 .{ }^{54}$ However, this circular also had limited impact. Consequently, on 10 August

53 It is evident from recent media reports that the Government is gradually adopting a hard stance against the unlawful omission of wearing masks. Please see response of the Cabinet Secretary to a query from a media perosonnel regarding the possibility of raising punishment against free-riding without masks. Ali Asif Shawon, 'Tk5,000 fine for not wearing a mask?' Dhaka Tribune (Dhaka, 23 November 2020) $<$ https://www.dhakatribune.com/bangladesh/2020/11/23/govt-considering-stricter-punishment-fornot-wearing-masks> accessed 7 February 2021.

54 'Bangladesh makes wearing of masks mandatory, DGHS resigns' (Medicircle, 22 July 2020) 
2020, the Cabinet, with Prime Minister Sheikh Hasina in the Chair, ordered field administrators to strengthen the execution of the circular which was issued in July. ${ }^{55}$ This limited implementation of current legislative responses can potentially have severe consequences, as experts anticipated the second wave of Corona transmission during the winter. ${ }^{56}$

\section{B. Legal Liability against 'Negligent' or 'Reckless' Movement of 'Free- riders': Lessons from Other Countries}

The purpose of this section is to demonstrate that despite differences in socio-economic conditions in UK, Singapore, India, Sri-Lanka and Bangladesh, the presence of 'special law with stringent punishment provisions' and 'strict implementation' of existing laws (such as, curfews) could be two effective tools for controlling the spread of Coronavirus pandemic.

\section{Legislative Response in the $U K$}

The Coronavirus Act 2020, one of the earliest Acts to restrict COVID-19 was passed in the UK on 25 March $2020^{57}$. The UK remains innovative, prompt and flexible in developing its legislative provisions against this deadly pandemic. The UK already has the Public Health (Control of Disease) Act 1984 to survive two other epidemics earlier. Nonetheless, the new Coronavirus Act 2020 was enacted by inserting provisions -"in connection with Coronavirus"; and "for connected purposes" ${ }^{\prime \prime 58}$. The interim nature of this special law can be understood from its Preamble. The Preamble of the Coronavirus Act 2020 declares:

[This] Act (except for specified provisions) expires at the end of 2 years beginning with the date of Royal Assent, see s. 89 (subject to s. 90); and a relevant national authority may by regulations suspend (and subsequently revive) the operation of any provision of this Act (except for those provisions listed in s. 88(6)), see s. $88 .{ }^{59}$

The Public Health (Control of Disease) Act 1984 still remains umbrella legislation which was enacted to consolidate certain enactments relating to the control of disease and to the establishment and functions of port health authorities, including enactments relating to burial and cremation and to the regulation of common lodging-houses and canal boats, with amendments to give effect to recommendations of the Law Commission. ${ }^{60}$ On the other hand, the Coronavirus Act 2020 includes many provisions

\footnotetext{
<https://www.medicircle.in/bangladesh-makes-wearing-masks-mandatory-news-cases-everyday> accessed 2 September 2020.

55 'Cabinet orders mobile court operation to ensure mask use' New Age (Dhaka, 10 Aug 2020) $<$ https://www.newagebd.net/article/113144/cabinet-orders-mobile-court-opeation-to-ensure-maskuse> accessed 12 September 2020.

56 The Daily Prothom Alo (n 14).

57 The Coronavirus Act 2020 (UK).

58 Ibid, Preliminary Text.

60 The Public Health (Control of Disease) Act 1984 (UK), Introductory Text.
}

59 Ibid.

Page | 188 
to meet emergencies, including the emergency recruitment of doctors, nurses and volunteers for a temporary period. New regulations to meet the Coronavirus emergency are still being made under several provisions of the Public Health Act 1984. Section 45 of the Public Health Act 1984 discussed legislative requirements for making such regulations under different contexts. ${ }^{61}$ For instance, as mentioned the Preamble to the Health Protection (Coronavirus, Restrictions) (England) (No. 4) Regulations, 2020 states that:

These Regulations are made in response to the serious and imminent threat to public health, which is posed, by the incidence and spread of severe acute respiratory syndrome Coronavirus 2 (SARS-CoV-2) in England.

In accordance with section 45R of the Act, the Secretary of State is of the opinion that, due to urgency, it is necessary to make this instrument without a draft having been laid out before, and approved by a resolution of each House of Parliament. ${ }^{62}$

According to Regulation 20(2) of Regulation 2020, an offence is punishable with fine on summary conviction. Regulation 20(5) states that Section 24 of the Police and Criminal Evidence Act 1984 applies concerning an offence under this regulation as if the reasons in subsection (5) of that section included-(a) to maintain public health or (b) to maintain public order. Regulation 21 includes fixed penalty provisions for violation of Coronavirus restrictions that support fair penalty and avoid partisan behaviour or corruption by law enforcement authority in this regard. ${ }^{63}$

Regulation 21 of the Police and Criminal Evidence Act 1984 further suggests an incremental penalty schedule for those who violate the regulation for the first time or second, third, fourth or many times hereafter. ${ }^{64}$ This differential penalty schedule is more appropriate for maintaining equity between the one-time offender and the frequent reckless offender who violates health regulations and endangers public health. Though UK is not a neighbouring country of Bangladesh, understanding the features of legislative responses made by the UK to restrain the spread of COVID-19 is imperative, as it constitutes the basic legislative structure of counties in this subcontinent.

\section{Legislative response in India}

India remains one of the most hard-hit countries in Asia by the COVID-19 pandemic. Although India already had the Epidemic Disease Act, 1897 in its legal domain, the main limitation lies in its quick and effective implementation ${ }^{65}$. There was serious concern whether the century-old law was enough to tackle a 21 -century pandemic. ${ }^{66} \mathrm{In}$

\footnotetext{
Ibid, s 45

62 Health Protection (Coronavirus, Restrictions) (England) (No. 4) Regulations 2020, Introductory Text Ibid, reg 21 (1).

Ibid, reg 21 (6).

65 The Epidemic Diseases Act 1897; Section 3 of the said Act provides that "Any person disobeying any regulation or order made under this Act shall be deemed to have committed an offence punishable under section 188 of the Indian Penal Code". Ibid.
}

66 
many cases, government officials seemed non-responsive due to lack of sufficient legal provisions applicable to current day scenarios. Public response to such offences, (e.g. not wearing a mask) was slow, a fact compounded by the nominal penalty prescribed for breach of the relevant law. ${ }^{67}$

India started to apply quarantine rules and impose lock-downs at about the same time as Bangladesh. However, as shown in Table 2 below, in the absence of a 'special law ${ }^{168}$ to tackle this unique pandemic and harsh punishment for violation of government regulations, the daily death toll of India sky-rocketed compared to other countries in the region, like Singapore, Malaysia, or Sri Lanka.

Table 2: Trend of newly detected cases and daily deaths in Asia

\begin{tabular}{lllllll}
\hline & \multicolumn{2}{c}{ New cases detected on } & \multicolumn{3}{c}{ New Death on } \\
Country & 8-Mar 2020 & $\begin{array}{l}\text { 2-Jun } \\
\mathbf{2 0 2 0}\end{array}$ & 1-Sep 2020 & $\begin{array}{l}\text { 8-Mar } \\
\mathbf{2 0 2 0}\end{array}$ & 2-Jun 2020 & 1-Sep \\
Bangladesh & 7 & 2381 & 2174 & 0 & 22 & $\mathbf{2 0 2 0}$ \\
India & 5 & 8171 & 69921 & 0 & 204 & 33 \\
Malaysia & 0 & 56 & 6 & 0 & 1 & 1 \\
Pakistan & 1 & 3938 & 300 & 0 & 78 & 4 \\
Singapore & 12 & 408 & 41 & 0 & 1 & 0 \\
Sri Lanka & 0 & 10 & 37 & 0 & 1 & 0 \\
\hline
\end{tabular}

Source: World Health Organization

Although India is a big country with a massive population, by the beginning of 1 September 2020, Indian death tolls passed a point beyond rationalisation by any comparative statistics. The Hindu analysed why India appeared to fail in containing the pandemic:

Both the UK and Singapore's laws set out unambiguous conditions and legally binding obligations. As such, under Singaporean law, the violators may be penalised up to $\$ 10,000$ or face six months imprisonment or both. In contrast, Section 188 of the Indian Penal Code has a fine amount of Rs.200 to Rs.1,000

67 According to s. 188 of the Indian Penal Code, "Whoever, knowing that, by an order promulgated by a public servant lawfully empowered to promulgate such order, he is directed to abstain from a certain act, or to take certain order with certain property in his possession or under his management, disobeys such direction, shall, if such disobedience causes or tends to cause obstruction, annoyance or injury, or risk of obstruction, annoyance or injury, to any person lawfully employed, be punished with simple imprisonment for a term which may extend to one month or with fine which may extend to two hundred rupees, or with both; and if such disobedience causes or trends to cause danger to human life, health or safety, or causes or tends to cause a riot or affray, shall be punished with imprisonment of either description for a term which may extend to six months, or with fine which may extend to one thousand rupees, or with both. Explanation: It is not necessary that the offender should intend to produce harm, or contemplate his disobedience as likely to produce harm. It is sufficient that he knows of the order which he disobeys, and that his disobedience produces, or is likely to produce, harm."

68 Manuraj Shunmugasundaram, 'India needs to enact a COVID-19 law' The Hindu (India, 8 May 2020) <https://www.thehindu.com/opinion/lead/india-needs-to-enact-a-covid-19-

law/article31529036.ece\#!> accessed 10 September 2020.

Page | 190 
or imprisonment of one to six months. Even then, proceedings under Section 188 can only be initiated by private complaint and not through a First Information Report. ${ }^{69}$

It follows, therefore, that several Asian countries, such as, Sri Lanka, Malaysia and Singapore, have successfully managed to fight the Coronavirus by what appears to be the stringent enactment and strict application of new law.

\section{Legislative response in Singapore}

When the pandemic was first detected in Singapore in January 2020, they immediately decided in a Ministerial meeting to apply some restrictions on public movement in line with the SARS Regulation used in $2003^{70}$. Later, on 7 April 2020, Singapore passed the COVID-19 (Temporary Measures) Act, 2020. Under this umbrella Act, the COVID-19 (Temporary Measures) (Control Order) Act, 2020 was passed to restrict public movement, control trade, social gatherings and other charitable activities. ${ }^{71}$ The country even amended its Constitutional provisions to enable parliament members to attend sessions online. Later, the Parliamentary Elections (COVID-19 Special Arrangements) Act, 2020 was passed in the Parliament to allow voters to cast their votes without coming to polling booths.

Although Singapore did not impose curfew to implement their quarantine rule like its Asian neighbours, it nonetheless made significant progress in bringing necessary amendments to its laws, enacting new laws and regulations and ensuring proper implementation of the same to contain the pandemic. As the comparative scenarios from the inception of the pandemic are revealed in Figure 1, Singapore has successfully controlled its Covid-19 induced death toll despite its much higher infection rate ${ }^{72}$. Despite a much weaker socio-economic condition compared to Singapore, Sri Lank similarly controlled the spread of the pandemic by way of curfews and lock-downs ${ }^{73}$.

\section{Figure 1: Cumulative number of COVID-19 cases detected in countries (March 2020 to} September 2020)

${ }^{69}$ Manuraj Shunmugasundaram, 'India needs to enact a COVID-19 law' The Hindu (India, 08 May 2020) $<$ https://www.thehindu.com/opinion/lead/india-needs-to-enact-a-covid-19law/article31529036.ece\#!> accessed 10 September 2020.

${ }^{70}$ Kevin Y. Tan, 'Singapore's Regulatory Response to COVID-19' The Regulatory Review (Singapore, 15 June 2020).

${ }^{71}$ The COVID-19 (Temporary Measures) (Control Order) Regulations 2020 (Singapore).

${ }^{72}$ For effective control on the spread of the COVID- 19 Pandemic, Singapore imposed hefty monetary penalty of USD 7000 along with a maximum of 6 months imprisonment to those who provide false information in this regard. See more, Oppah Kuguyo, Andre P Kengne, and Collet Dandara, 'Singapore COVID-19 Pandemic Response as a Successful Model Framework for Low-Resource Health Care Settings in Africa?' (2020) 24(8) OMICS 470.

${ }^{73}$ Police patrol or even deployment of Army was also observed in UK, Spain, Italy and South Africa for an effective implementation of lock-down. See more, Ibid. 


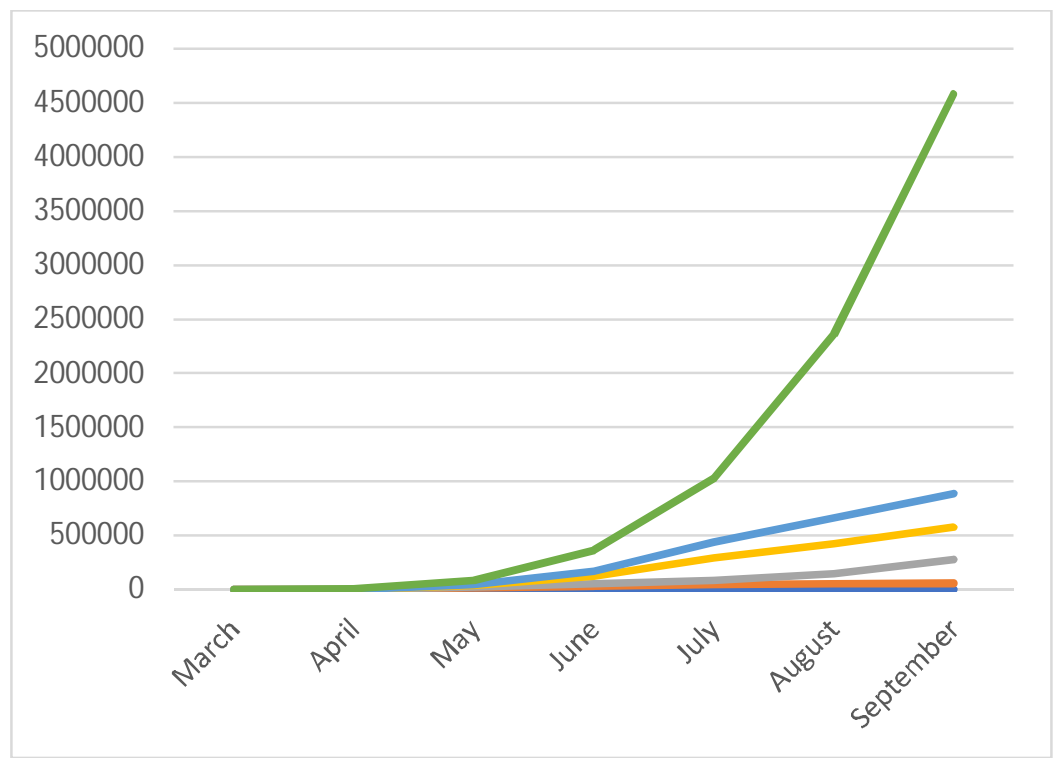

India

Bangladesh

Pakistan

Philippines

Singapore

Sri Lanka

Source: World Health Organization, 'WHO Coronavirus Disease (COVID-19) Dashboard'

It is evident from the above Figure that although compared to India and Bangladesh, the detection of COVID-19, which started in January 2020, was initially high in Singapore. Proper implementation and compliance with health directives have been effective in reducing new cases. ${ }^{74}$ India and Bangladesh, both of which started to detect Coronavirus cases in March 2020, began with a low base. Gradually, their trend of seeing new patients surpassed that of Singapore ${ }^{75}$.

\section{Legislative response in Sri Lanka}

On 20 March 2020, only a couple of days earlier than Bangladesh and India, Sri Lanka imposed a lock-down to restrain the spread of COVID-19. The Sri Lankan authorities announced a three-day nationwide 'curfew' to curb the spread. The nationwide curfew started at 18:00 (local time) on Friday, 20 March 2020, and lasted until 06:00 on Monday, 23 March, during which individuals were prohibited from leaving their homes except for essential needs. This 24-hour curfew continued for a month during which the length of the curfew was gradually relaxed spanning from midnight to $4 \mathrm{AM}^{76}$ Once the curfew was withdrawn, Sri Lanka started to impose lock-down of different degrees. This early imposition of curfew under the 'doctrine of necessity' helped this island nation to create sufficient social awareness about the gravity of the pandemic

74 'WHO Coronavirus Disease (COVID-19) Dashboard' (WHO Website) <https://covid19.who.int/? gclid> accessed 16 September 2020.

75

76

Editorial, 'Sri Lanka completely lifts coronavirus curfew as no community infection in nearly two months' The Indian Express (Chennai, 28 June 2020) <https://www.newindianexpress.com/ world/2020/jun/28/sri-lanka-completely-lifts-coronavirus-curfew-as-no-community-infection-innearly-two-months-2162628.html> accessed 08 March 2021. 
and the response required in this regard.

As indicated in Figure 1 above, the cumulative detection of COVID-19 patients in India alone was much higher than any other country depicted here. Since India has a vast population, it is not unseemly for the number of COVID-19 patients in India to be increased. What is alarming is that the detection of new COVID-19 cases in India. As indicated by the trend line, the rate of new patients have increased every month and made the trend line steeper over time. On the other hand, Bangladesh, Pakistan and the Philippines managed to hold a moderate increase over time. Singapore and Sri Lanka were most successful in keeping the cumulative detection rate almost flat over time. While Pakistan's total population is larger than the total population in Bangladesh, the incremental detection of Covid cases in Pakistan was higher than in Bangladesh. Similarly, Sri Lanka has managed to keep the number of Covid cases low despite having a dense population, which is three times more than the population of Singapore. It therefore appears, that both legislative and administrative responses based on prompt and stringent penalties effectively controlled the pandemic in these countries.

\section{DOES THIS ONLY QUALIFY AS A 'NEGLIGENT' PUBLIC NUISANCE OR CAN IT BE DEEMED TO BE A 'RECKLESS' PUBLIC HEALTH OFFENCE?}

Prior to the detection of the novel' Coronavirus in Bangladesh on 08 March 2020, the spreading of the infectious disease endangering life was dealt with under s. 269 (Chapter XIV relating to public nuisance) of the Code, 1860 as follows:

Whoever unlawfully or negligently does any act which is, and which he knows or has reason to believe to be, likely to spread the infection of any disease dangerous to life, shall be punished with imprisonment of either description for a term which may extend to six months, or with fine, or with both (s. 269).

The same punishment, i.e. "six months, or with fine" has also been incorporated in Section 291 of the Code 1860 for reckless or repeat public nuisance that is indeed being done by reckless 'free riders' by repeatedly violating health regulations during the COVID 19 pandemic. By the passage of time, in 2018, another special law was enacted to regulate negligent behaviour of an individual that may transmit noxious and infectious diseases; this has already been declared a criminal activity by the 2018 Act.

As stated earlier, the Mobile Courts Act, 2009 has already included relevant sections of the Schedule 2018 Act. However, as a general law, the Code, 1860, considered this crime within the ambit of an offence relating to 'public nuisance' (i.e. Chapter XIV) and imposed a minimal penal provision, while the Act of 2018, imposed a comparatively higher penalty. Careful consideration of section 24(1) of the Act of 2018 indicates that a maximum penalty of Tk.100,000 has been imposed, which is sufficient to curb frequent violations if it is rigorously implemented. The Act of 2018 failed to effectively distinguish punishment between single negligent violators and reckless frequent or recurrent violators of health regulations, as was done, for instance, in the UK and Singapore. 
Despite several warnings from WHO and other international organisations regarding possible spread throughout the world, many countries, including Bangladesh, did not seem to take these seriously, which resulted in wide community transmission throughout the country. At this point, it would not be exaggerated to mention that the Coronavirus spread in Bangladesh rapidly expanded since 08 March 2020 until 30 September 2020 whereby the death toll had already passed 5,231. Notwithstanding, many people in Bangladesh are 'free-riders' going about normally without wearing masks, and adopting other preventive measures, knowing full well that they might be posing risks for others, including death by their indirect attribution to aggregate harm to others. Sadly, they will simply be liable for offences relating to 'negligent' public nuisance under s. 269 of the Code, 1860 or a minimum penalty under the Act 2018. Unless stricter punishments are in place and unless relevant laws are strictly enforced, these 'free-riders' will continue to pose health risks for others. Alternatively, their criminal liability should go beyond the notion of a 'negligent public nuisance' and extended to 'reckless public health offence', which is likely to deter repeat occurrences of negligence.

\section{CONCLUSION}

The stringent implementation of the law was successful in curbing the spread of COVID-19 in many Asian countries. As the potential of the virus reaching more people across more significant geographic coverage increase in Bangladesh, a legislative response with a rigorous implementation like in other countries can be more appropriate to encompass the pandemic effectively. Although, in contemporary political culture, the declaration of an emergency ${ }^{77}$ by using the Constitutional provisions could create controversies among legal scholars, yet the imposition of curfew would be possible under the Special Powers Act, 1974 to restrain free movement and in turn, to contain the deadly disease. ${ }^{78}$ The imposition of curfew was effectively employed in some countries to curb the spread of this life-threatening disease. Drawing on lessons from other countries in South and East Asia, this paper suggests some amendments to the 2018 Act. Although the Act imposes a hefty fine, the slack implementation does minimal to address the emergency. This could have severe implications for future waves of the infection. Thus, it is high time for

77 For example, the Philippines has promulgated 'emergency' in order to curb the COVID-19 pandemic, which came into existence on 24 March 2020 and was initially effective for three months only then further extended up to 30 September 2020 (s.9). See more on The Corona Virus Act, 2020 of Philippines (Republic Act No. 11469), where s. 2 states that "State of national emergency Presidential Proclamation No 922, s.2020, was issued declaring a State of Public Health Emergency throughout the Philippines due to the Coronavirus disease 2019 (COVID-19) in accordance with the recommendation of the Department of Health $(\mathrm{DOH})$ and the Inter-Agency Task Force for the Emerging Infectious Disease". In order to mitigate any debate on the said national emergency, section 7 of the same Act 2020 clarifies that," Nothing herein shall be construed as an impairment, restriction or modification of the provisions of the Constitution. In case the exercise of powers herein granted conflicts with other statutes, orders, rules or regulations, the provisions of the Act shall prevail". The Philippines Official Gazette, <https://www.officialgazette.gov.ph/downloads/2020/ 03mar/20200324RA-11469-RRD.pdf> accessed 26 September 2020.

78 The Special Powers Act 1974, s 24(1).

Page | 194 
Bangladesh to amend the law and incorporate 'differential penal provisions' distinguishing 'first-time negligent offenders' from 'frequent reckless offenders' who repetitively violate the health guidelines. The law should ensure that 'free-riders' who recurrently do not comply with health guidelines of the concerned authority, will be criminally liable to the extent that the act of 'negligent public nuisance' should be extended to a 'reckless public health offence'. Indeed, the need for efficient mobile court operations could not be emphasised more in addition to creating strong social awareness $^{79}$ in order to induce the desired deterrent effect and curb the spread of the 'invisible enigma' of the Century.

79 According to the Act of 2018, the purpose of its enactment was to prevent, control, and eradication of communicable diseases and raise public awareness to deal with public health emergencies and reduce health hazards. As Bangladesh is a lower-middle income country with numerous illiterate people living in urban slums and villages, continuing lockdown, strict maintenance of health regulations and enhanced testing and healthcare facilities are suggested as frontline measures to tackle this situation. See, Saeed Anwar, Mohammad Nasrullah and Mohammad J Hosen, 'COVID-19 and Bangladesh: Challenges and How to Address Them' (2020) 8 Frontiers in Public Health <https://www.ncbi.nlm.nih.gov/pmc/articles/PMC7203732/> accessed 08 February 2021. 